\title{
Trabajos recientes realizados por el grupo de resistencia probabilística de materiales del IDIEM
}

\section{Recent works carried out at the IDIEM by the group in charge of probabilistic strength of materials}

\begin{abstract}
Fecha de recepción: 18-XII-1989
\end{abstract}
P. KITTL, G. DIAZ

Departamento de Ciencias e Ingeniería de Materiales, IDIEM

Facultad de Clenclas Fisicas y Matemátlcas

Universidad de Chile

Casilla 1.420, Santiago, CHILE

\section{RESUMEN}

Se describen, desde un punto de vista conceptual, todos los trabajos desarrollados hasta la fecha por el grupo de Resistencia Probabilistica de Materiales del IDIEM asi como los que están actualmente en ejecución. Se consideran tres aspectos en la descripción. En primer lugar, se comentan los objetivos generales de la disciplina discutiendo su fundamentación teórica. En segundo lugar, se analizan casos de materiales sometidos a esfuerzos de tracción, compresión, corte, flexión, torsión, flexión excéntrica, pandeo, compresión y tracción excéntricas y la consecuente determinación de los parámetros de la función de Weibull en todos ellos. En tercer lugar, se mencionan las aplicaciones que esta disciplina tiene en la ingenieria, tales como en: mecánica de suelos, mecánica de rocas, fatiga, pavimentos de hormigón, sismologla, industria nuclear, entre otras. Por último, se hace una sucinta descripción de los trabajos en curso.

\section{SUMMARY}

This updating review describes, from the conceptual standpoint, all the research works so far carried out at the IDIEM by the group in charge of Probabilistic Strength of Materials as well as research activities under way at present. This description considers three aspects. First, the general purposes of the commented discipline and the discussion of its theoretical foundations are presented. In the second place, an analysis is conducted in connection with materials subjected to diverse stresses of tension, compression, shearing, bending, torsion, eccentrical bending, and also subjected to buckling, eccentrical compressive and eccentrical tensile stresses; in all these cases the pertaining parameters of Weibull's function are determined. Thirdly, sundry engineering applications of said discipline are set out in such fields as, for example, soil mechanics, rock mechanics, seismology, nuclear reactors industry, fatigue, and concrete pavements. At last a brief description of research work now in progress is given.

\section{INTRODUCCION}

En un trabajo relativamente reciente de Kittl, Díaz y León se comentaron los trabajos que hasta esa fecha se realizaron por este grupo de trabajo [1-27]; en esa puesta al día [28] están bastante detallados los objetivos de esta disciplina así que, en la presente puesta al día, se discutirán los trabajos posteriores [29-75] en una forma esencialmente conceptual.

\section{OBJETIVOS GENERALES DE LA RESISTENCIA PROBABILISTICA DE MATERIALES}

Estos objetivos pueden dividirse en tres grandes líneas. La primera línea

\section{INTRODUCTION}

A relatively recent paper by Kittl, Dlaz and León has commented the sundry research work carried out by this group [1-27]; that up-dating paper [28] contains a fairly detailed review of the purposes of this discipline, and therefore the present up-dating paper will discuss the later work [29-75] from an essentially conceptual viewpoint.

\section{GENERAL PURPOSES OF PROBALISTIC STRENGTH OF MATERIALS}

These purposes can be subdivided into three extense lines of research. The first 
corresponde a la fundamentación [2, 12 , $15,17,24,35,44,49,53,58-59,61,63$, 72] cuyo objetivo fundamental, no sólo es determinar la forma de la función de probabilidad acumulativa de fractura 0 fluencia definida por Weibull, sino demostrar en forma ineludible la dependencia de ésta con respecto al volumen. Debe entenderse, perfectamente bien, que se trata de la propagación de la primera grieta que produce la aplicación de una tensión. Esa propagación, en el caso de un material frágil sometido a tracción, producirá su rotura catastrófica. $Y$ en el caso de los materiales dúctiles es la tensión que comienza a movilizar las dislocaciones, es decir, la tensión de fluencia. Estas demostraciones contienen todas teoremas de unicidad que hacen ineludible su cumplimiento; en caso de que esto no ocurra y que no haya la dependencia del volumen establecida, esto significa que debe propagarse más de una grieta para que se verifique una fractura catastrófica. Es creencia general que estas leyes no son válidas en compresión sino sólo por tracción, como si aparte de la propagación de una grieta por tracción en sus bordes no pudiera haber propagación de grietas por corte, como debe ocurrir en compresión. Los materiales muy frágiles como el vidrio presentan, incluso en compresión, una dependencia con el volumen, que indica que la rotura es catastrófica en esas condiciones de tensión. Todo esto nos lleva a la teoría de los cuerpos cuasi-frágiles, que necesitan la propagación de un cierto número crítico de grietas, en un volumen crítico - siendo ambas constantes del material-; en el caso de que esto no sea así, se deben tomar promedios [21-22, 30, 35, 54].

La segunda línea corresponde a los esfuerzos de flexión, torsión, flexión excéntrica, pandeo, compresión o tracción excéntrica y por supuesto la determinación de los parámetros de la función de Weibull en todos estos casos y, además, en los de tracción, compresión y corte por diferentes métodos estadísticos.

En caso de suponer que la función de Weibull no es conocida, esto implicaría la solución de ecuaciones integrales con todos los problemas relativos a su existencia, solución numérica y naturaleza de sus soluciones analíticas. Además, debe recordarse que los materiales compuestos tienen aquí una parte importante. line relates to the establishment of the foundations $[2,12,15,17,24,35,44,49$, $53,58-59,61,63,72]$, whose main purpose is not only determining the form assumed by the function of the cumulative probability of fracture or yielding defined by Weibull, but also showing in an unavoidable way the dependence of this function on volume. It should be perfectly understood that the foregoing refers to the propagation of the first crack caused through the application of some stress. In the case of a brittle material subjected to a tensile stress this propagation will produce the catastrophic fracture thereof. And in the case of ductile material it is the stress that starts mobilising the dislocations, i.e. yielding stress. All these demonstrations contain unicity theorems that render compliance therewith unavoidable; if not so and if the established dependence on volume does not apply, then this means that more than one crack must propagate in order to give rise to some catastrophic fracture. There is a general belief that these laws are not valid on compression and that thus they apply only on traction, as if aside from crack propagation through tensile stresses applied to crack edges there could not arise some crack propagation through shearing stresses, as it must occur in compression. Very brittle materials such as glass are exhibiting, even in compression, a volume dependence, which indicates that fracture is catastrophic under these stress conditions. All this leads to the theory of almost-brittle bodies requiring the propagation of a certain number of cracks through a critical volume, both being constants of the material; if not so, mean values are to be taken [21-22, $30,35,54]$.

The second line of research relates to bending, torsion, eccentrical bending, buckling, eccentrical compression or traction stresses and, of course, to the determination of Weibull's function parameters in all these instances as well as, in addition, in all those cases of traction, compression and shearing, using therefor diverse statistical methods. When supposing that Weibull's function is unknown, this implies the solving of integral equations with all the problems regarding the existence of the same, their numerical solution, and the nature of their analytical solutions. Besides, it should be remembered that compound materials are playing an important role here. 
Por último, son las aplicaciones a la ingeniería las que tienen la importancia necesaria para ocupar un lugar preponderante como: mecánica de suelos, mecánica de rocas, sismología, durabilidad de reactores nucleares y fatiga, por nombrar sólo algunas.

\section{RESISTENCIA PROBABILISTICA DE PIEZAS SOMETIDAS A ESFUERZOS ELEMENTALES}

Con respecto a los esfuerzos más elementales como compresión, tracción y corte, la determinación de los parámetros de la función de Weibull se ha realizado por el método de los nomogramas; el analítico, el de máxima verosimilitud; el de momentos, el del mínimo chi-cuadrado; el de mínimos cuadrados [4-5, 9-10, 12 , $16-17,21-22,25,27,29-31,33,36-37,45$, $54,56,65-66,71]$, y finalmente un ajuste con polinomios ortogonales de Legendre, el cual ha demostrado que la función de Weibull es la que mejor se ajusta [47].

Para el caso de ensayos de flexotracción, mediante el ensayo de flexión de tres puntos, se han determinado los parámetros de Weibull, tanto en fragilidad volumétrica como superficial, para vigas de secciones rectangular y circular considerando el método de las funciones definidas con tensión límite inferior nula y no nula; también con el método de las ecuaciones integrales se ha obtenido la función riesgo especifico de fractura $[1-3,7-9,11,13-14,16,18,22-23$, $26,29,31,35-36,39,43,51,56,58]$. Todo lo anterior se ha empleado en conjunto con los nomogramas, el método del chi-cuadrado y los polinomios ortogonales de Legendre para determinar los parámetros de la función de Weibull. También se ha tomado en cuenta la corrección de Seewald-Karman por tratarse de un ensayo con carga puntual $[40,42]$.

Ultimamente hemos venido desarrollando el ensayo de torsión de barras de diferente sección con la respectiva determinación de los parámetros de la función de Weibull considerando además las fragilidades volumétrica y superficial, empleando para ello funciones definidas con tensión límite inferior nula y no nula, nomogramas, chi-cuadrado y ecuaciones integrales. Las secciones estudiadas hasta la fecha son: rectangular, cuadrada, triangular, poligonal equilátera de $n$ lados, circular y elíptica $[37,41,46,48,52,57,68]$. La parte experimental la está desarrollando el
Finally, engineering applications are those exhibiting the required significance in order to occupy an outstanding place in such fields as soil mechanics, rock mechanics, seismology, nuclear reactors durability, and fatigue, to mention some ones only.

\section{PROBABILISTIC STRENGTH OF PARTS SUBJECTED TO ELEMENTAL STRESSES}

The determination of Weibull's function parameters for the most elemental stresses, as in compression, traction and shearing, has been carried out using very diverse procedures such as the nomogram, analytic, maximum-likelihood, moments, minimum $\chi^{2}$, and least-squares methods [4-5, 9-10, 12, 16-17, 21-22, 25, 27, 29-31, 33, 36-37, 45, $54,56,65-66,71]$, and at last a curve-fitting method using Legendre's orthogonal polynomials, which has shown that Weibull's function is the one supplying the best fit [47].

For the case of flexotraction using the 3-point bending test, Weibull's parameters regarding both volume and surface brittlenesses for rectangular and round beams, have been ascertained resorting to the defined functions method with null and non-null lower limit-stress, as well as using the integral equations method, thus obtaining the specific-risk-of-fracture function $[1-3,7-9,11,13-14,16,18,22-23,26,29$, $31,35-36,39,43,51,56,58]$. All the foregoing has been used along with the nomograms, the $\chi^{2}$ method, and Legendre's orthogonal polynomials, to the end of getting Weibull's function parameters. The Seewald-Karman correction has been also taken into account owing to the fact of dealing with a puntual-load test [40, 42].

These last times we have been developing the torsion test applied to bars of varied cross-sections, and then the appertaining parameters of Weibull's function have been determined considering, besides, volume and surface brittlenesses and using therefor defined functions with null and non-null lower limit-stress, as well as nomograms, $\chi^{2}$ and integral equations. Thus far the cross-sections studied are those rectangular, square, triangular, polygonal $n$-side equilateral, round, and elliptical $[37,41,46$, $48,52,57$ 68]. Experimental work has been undertaken together with the 
alumno memorista del Departamento de Ingeniería Mecánica, Sr. Víctor Martínez.

Otro ensayo que se ha considerado es el de carga excéntrica, tanto en tracción como en compresión, aplicada en piezas prismáticas de secciones rectangular y circular. Para las fragilidades volumétrica y superficial, con tensión límite inferior nula y no nula y usando el método de las funciones definidas es posible determinar los parámetros de la función riesgo específico de fractura. Con el método de las ecuaciones integrales se ha estudiado la fragilidad volumétrica y superficial conjunta y se las ha podido separar. Varias son las zonas que se pueden identificar en la pieza ensayada; a cada zona le corresponden respectivos parámetros de Weibull [75]. Lo anterior está siendo abordado por el Sr. Martínez.

Resuelto el caso anterior de carga excéntrica se encara el estudio de la compresión de piezas esbeltas, es decir, el pandeo de pilares y columnas sometidas, en general, a cargas excéntricas para secciones rectangulares y circulares. Mediante el análisis de las deformaciones inducidas por cargas de diferente excentricidad, se puede determinar la flecha respectiva y la probabilidad acumulativa de fractura asociada: luego se puede entonces obtener la excentricidad efectiva de la columna o pilar haciendo en ésta un seccionamiento hipotético perpendicular a su eje [64]. Como en el trabajo anterior éste corre a cargo del Sr. Martínez.

También es interesante determinar la probabilidad de fractura en distintos puntos de un mismo cuerpo, es decir, la probabilidad local de fractura. Tales determinaciones se han hecho para los ensayos de flexotracción en vigas de secciones rectangular y circular $y$ en ensayos de pull-out donde se extraen fibras desde el interior de una matriz. Lo anterior se ha resuelto mediante el método $d e$ las funciones definidas $y$, actualmente, se está introduciendo el método de las ecuaciones integrales a este problema [3, $6,10,19,27,31,33,35-36,38,67]$.

\section{APLICACIONES DE LA RESISTENCIA PROBABILISTICA DE MATERIALES A LA INGENIERIA}

A continuación se describen brevemente algunas aplicaciones a la ingeniería de la disciplina que se está desarrollando. memoirist-student Victor Martínez, from Mechanical Engineering Department.

Another test taken into consideration is eccentric testing on traction as well as on compression, applied to rectangular and round prismatic parts. In the events of volumen and surface brittlenesses with null and non-null lower limit-stress, the use of the defined functions method allow to get the parameters of the specific-risk-of-fracture function. The integral equations method has been employed to study volume and surface combined brittleness and to separate these two kinds of brittleness. The zones than can be identified in the tested part are varied and each one has appertaining Weibull's parameters [75]. The foregoing is being investigated by Mr. Martínez.

Once the above case of an eccentric load has been solved, there begins the study of compression in slender parts, that is of buckling in pillars and columns withstanding generally eccentrical loads and rectangular or circular in cross-section. The analysis of the deformations caused by diversely eccentrical loads allows to calculate the corresponding deflection along with the associated cumulative probability of fracture; hence the actual eccentricity of the pillar or column can be obtained then by considering an hypothetical cross-section of this part, at right angles to its axis [64]. This work, the same as the preceding one, is being studied by Mr. Martínez.

Another interesting determination is that of fracture probability at different points of a given body, i.e. the appertaining local probability of fracture. Such determinations have been made in the cases of flexotraction tests applied to rectangular and round beams, as well as in the case of pull-out tests through which fibres are extracted from the inside of some matrix. The foregoing has been solved by resorting to the defined functions method, and now the integral equations method is being applied to this problem $[3,6,10,19,27$, $31,33,35-36,38,67]$.

\section{APPLICATIONS OF PROBABILISTIC STRENGTH OF MATERIALS TO ENGINEERING}

The following is a brief description of some engineering applications of the discipline that is being developed. 
En las estructuras generalizadas, hiperestáticas 0 no, y en particular en las reticuladas se puede determinar la probabilidad acumulativa de fractura 0 fluencia considerando no sólo sus barras sino también sus uniones, las cuales pueden estar soldadas, remachadas 0 apernadas. Tanto las barras como las uniones conectoras pueden estar sujetas a diversas solicitaciones mecánicas y los materiales involucrados pueden ser frágiles y/o dúctiles. Luego la probabilidad acumulativa complementaria de fractura o fluencia se determina multiplicando las probabilidades acumulativas complementarias de cada uno de los miembros de la estructura [16, 25, 35].

Se ha aplicado esta disciplina a la Mecánica de Suelos y a la Mecánica de Rocas. En Mecánica de Suelos se ha determinado la probabilidad acumulativa de fractura o fluencia de fundaciones de columnas de sección circular y paredes de sección rectangular, empleando en ello los campos de tensiones de Boussinesq y Flamant, respectivamente. Si la columna o la pared están fundadas sobre roca se trata de probabilidad acumulativa de fractura y si la fundación es de tierra se trata entonces de probabilidad acumulativa de fluencia [32, 35]. En Mecánica de Rocas se ha estudiado el caso de un túnel y se ha resuelto la paradoja de la Teoría de la Elasticidad que dice que para cualquier tamaño de túnel la probabilidad de fractura sería la misma, hecho que no está de acuerdo con la realidad. Mediante la consideración del efecto de tamaño en la función de probabilidad de Weibull dicha paradoja queda resuelta. Se puede además determinar la zona que va desde la cara interna del túnel hasta una región determinada en la que la falla del mismo es por tracción, hecho que ha podido constatarse en excavaciones mineras que requieren túneles $[35,44]$.

El problema de la fatiga es de gran interés, no sólo desde un punto de vista teórico, sino también desde uno experimental y principalmente en grandes e importantes estructuras, de diferente naturaleza, que deben ser capaces de resistir solicitaciones de carácter cíclico, aleatorias o no. Aquí se ha formulado una solución general en la cual se estudia cómo se van modificando los parámetros de la función de Weibull a medida que el proceso de fatiga avanza. Tal modificación en los parámetros inducen cambios en la
In the generalised structures either hyperstatical or not and particularly in truss structures, the cumulative probability of fracture or yielding can be determined by considering not only their bars but also their linking unions, which can be welded, riveted or bolted. Both bars and linking unions can be subjected to diverse mechanical stresses and the materials involved can be brittle and/or ductile. Hence the complementary cumulative probability of fracture or yielding is obtained by multiplying the complementary cumulative probabilities of the different members composing the structure [16, 25, 35].

This discipline has been applied to Soil Mechanics and to Rock Mechanics. The cumulative probability of fracture or yielding in Soil Mechanics has been ascertained for the foundations of round colums and of walls having rectangular cross-sections, using to this end the field stresses of Boussinesq and of Flamant, respectively. If the column or wall foundations are built on rock, then the cumulative probability of fracture applies, and if they are built on earth the cumulative probability of yielding applies [32, 35]. The instance of a tunnel in Rock Mechanics has been studied, and there has been solved the paradox of Elasticity Theory stating that fracture probability would be the same for whatever tunnel size, which fact is not in keeping with reality. This paradox is now solved by considering size-effect in Weibull's probability function. In addition, the zone extending from tunnel inside to a determined region where failure is caused by tensile stress, can be ascertained and this fact has been actually verified in mining excavations requiring tunnels $[35,44]$.

Fatigue problem is highly interesting not only from the theoretical viewpoint but also from the experimental one, chiefly in large and important structures of varied nature and that must be able to withstand cyclic stresses either random or not. Here a general solution has been formulated, and the same allows to study how Weibull's parameters are modified as fatigue process is progressing. Such modification in the parameters gives rise to changes in the cumulative probability of fracture or yielding. The associated experimental phase requires 
función de probabilidad acumulativa de fractura o fluencia. La fase experimental asociada requiere de un gran número de experiencias las cuales están a cargo del Profesor Claudio Urrutia [35, 44].

Otro problema de interés, particularmente para Chile, es el de los grandes sismos y que ha sido tratado por nosotros al estudiar las probabilidades de ocurrencia y las magnitudes asociadas de grandes terremotos después que ha sobrevenido uno de magnitud mayor o igual que seis. Este ensayo de fractura que nos brinda gratuitamente la naturaleza es el de mayor envergadura respecto del tamaño del material fracturado y muestra por otra parte el amplio espectro de aplicación de la Resistencia Probabilística de Materiales [34].

Siguiendo con las aplicaciones a la ingeniería otra que reviste importancia es el empleo de la disciplina que nos ocupa en pavimentos de hormigón. Se trata aquí, básicamente, de un problema de fatiga en el cual la aleatoriedad de las cargas aplicadas, tanto en tiempo como en peso, inducen un efecto de fatiga mecánica sobre los caminos de hormigón. En fecha reciente se ha estudiado el reforzamiento de placas de pasta pura de cemento mediante la incorporación de fibras de cobre y el resultado que se obtiene es la probabilidad acumulativa de fractura al reparar placas fracturadas con empleo de resinas epóxicas $\theta$ inducir por este intermedio su efecto en pavimentos de hormigón, considerando que los parámetros, que describen el comportamiento a la compresión del hormigón, se obtienen de pastas puras de cemento a la compresión ya que dichos parámetros permanecen inalterados [50].

Para terminar con las aplicaciones, que se han estudiado hasta la fecha, habría que mencionar los contenedores esféricos sometidos a presión interna, contenedores usados como reactores nucleares en la industria nuclear. Se ha estudiado en ellos la probabilidad acumulativa del inicio de la fluencia, considerando para los mismos fluencias volumétrica y superficial, además de la existencia de cordones de soldadura que unen hemisferios, que están en planos no ecuatoriales, de los cascarones esféricos. Se trata principalmente del inicio de fluencia por tracción. Problema que ha sido enfocado principalmente desde el punto de vista de la Mecánica de Fractura y cuya solución es muy intrincada. En a large number of practical experiments, which are being conducted under Professor Claudio Urrutia's supervision [35, 44].

Another problem of special interest to Chile is that of strong seims, dealt with by us studying the probabilities of occurrence and the associated magnitudes of strong earthquakes upon the happening of some seism having a magnitude at least equal to 6. This fracture test gratuitously supplied by Nature is the largest one concerning fractured material and, on the other hand, it is showing the wide range of application of Probabilistic Strength of Materials [34].

\section{Continuing to consider the diverse} engineering applications, a further significant one is the use of the discussed discipline in concrete pavements. Basically, a fatigue problem is involved, wherein both time and weight randomness of applied loads induce a mechanical fatigue in concrete highways. A recent study has been made on the strengthening of neat-cement slabs through the addition of copper fibres, and on the result obtained in the cumulative probability of fracture when repairing fractured slabs by means of epoxi resins, and thus inducing the appertaining effect on concrete pavements. Considering that the parameters describing concrete behaviour on compression are obtained from neat-cement pastes subjected to compression inasmuch as said parameters remain unchanged [50].

The above review of the sundry applications studied to date will be ended here by mentioning the spherical vessels submitted to internal pressure and used as nuclear reactors in the nuclear industry. The cumulative probability of yielding-start has been studied in these vessels by considering surface and volume yieldings in addition to the existence of welding beads located in non-equatorial planes and joining the hemispheres of the spherical shells. Such yielding initiation is mainly due to tensile stress. The problem has been dealt with chiefly from Fracture Mechanics standpoint, whose solution is very involved indeed while using Probabilistic Strength of 
cambio, con el uso de la Resistencia Probabilística de Materiales, su solución se ve notoriamente simplificada $[44,49]$.

\section{BREVE COMENTARIO SOBRE LOS TRABAJOS EN ELABORACION}

Actualmente este grupo de trabajo cuenta con 44 publicaciones en la especialidad que se comenta, a lo cual habría que agregar 8 trabajos que están prontos a ser publicados y 23 trabajos en elaboración. Se han discutido ya los primeros trabajos; corresponde ahora dar una idea sucinta de los trabajos que están en curso.

De acuerdo con la línea relativa a los esfuerzos elementales y a la consiguiente determinación de los parámetros de la función de Weibull se está desarrollando un grupo de 12 trabajos que contemplan el ensayo de hendimiento o ensayo brasilero [55], ensayos de flexión en aleaciones fundidas [56] y en granito [65], ensayos de adherencia en la interfase granito-cemento [66], ensayos de torsión en barras de variadas secciones $[57,68]$, pandeo de columnas de diferentes secciones [64], ensayos de carga excéntrica [75] y ensayos de recipientes esféricos y cilíndricos sometidos a presión [69]. Unido a lo anterior se contempla, además, la compatibilización de la función riesgo específico de Weibull mediante el sometimiento a diferentes ensayos para un mismo material [71]. Se consideran también los campos triaxiles y los promedios de las tensiones, en dichos casos [70, 74].

Desde el punto de vista del método de las ecuaciones integrales se encuentran en ejecución los siguientes temas: solución de la ecuación integral de la Resistencia Probabilística de Materiales en términos de un operador diferencial finito [58]; determinación de las autofunciones de dicha ecuación integral para el caso de la flexión [61]; solución de la ecuación integral de la probabilidad local de fractura en el caso de flexión de vigas de secciones rectangular y circular [67]; distribución de grietas solucionando la ecuación integral y determinación del factor de tenacidad crítica [73].

Se encuentra en análisis una modificación a la función de Weibull, considerando para ello un espectro continuo del parámetro módulo de Weibull [72]. Se está estudiando
Materials simplifies the solution a great deal [44, 49].

\section{BRIEF COMMENT ON WORKS UNDER PREPARATION}

So far this research-work group has already published 44 papers on the commented discipline; in addition, 8 papers are about to be published and 23 papers are under preparation at present. As the first-mentioned papers have been already discussed, the following comments will supply a succinct idea on the works now under way.

In keeping with the line of investigation covering elemental stresses and the corresponding determination of Weibull's function parameters, a set of 12 works is being developed and the same includes the Brazilian, or splitting, test [55], bending tests on cast alloys [56] and on granite [65], adherence tests regarding granite-cement interface [66], torsion tests on bars with diverse cross-sections [57, 68], buckling in columns with different cross-sections [64], tests under eccentric loads [75] and on spherical and cylindrical containers subjected to pressure [69]. In addition to the above, the compatibleness of Weibull's function of specific risk through different tests applied to a given material is contemplated [71]. Triaxial fields and stress averages are also considered in said cases $[70,74]$.

The following topics are being studied from the viewpoint of integral equations method: solution of the integral equation of Probabilistic Strength of Materials in terms of some finite differential operator [58]; determination of the autofunctions of said integral equation for the instance of bending [61]; solution of the integral equation of local probability of fracture in the case of rectangular and round beams subjected to bending [67]; cracks distribution solving an integral aquation and determination of the factor of critical tenacity [73].

A modification to Weibull's function using therefor a continuous spectrum of Weibull's modulus parameter [72] is being analysed now. Furthermore, the relationship between 
la relación entre la Resistencia Probabilística de Materiales y la Mecánica de Fractura, relación que es posible establecer a través de la función de Weibull [59].

Finalmente hay una serie de 3 trabajos que tienen importancia en el ensayo de materiales como son el control de calidad, las condiciones de contorno aleatorias y la fatiga. En el primero de ellos se intenta establecer regiones de aceptación y rechazo al ensayar materiales frágiles, definiendo para ello los límites entre los cuales deben variar los parámetros de Weibull y el número necesario de muestras a ensayar para que el referido ensayo tenga validez estadística [60]. En el segundo trabajo se está estudiando teórica y experimentalmente, bajo la dirección del Profesor Urrutia, la influencia que tienen las condiciones de contorno de un determinado ensayo en las tensiones de fractura, puesto que sumado a la aleatoriedad del material hay que considerar aleatoriedad en tales condiciones de contorno [62]. En el tercer trabajo, también bajo la supervisión del Profesor Urrutia, se está investigando el proceso de fatiga mecánica inducida en materiales compuestos, específicamente en el compuesto fibra de cobre-cemento compactado, teniendo como marco teórico la solución general propuesta al problema de la fatiga en el ámbito de la Resistencia Probabilistica de Materiales [63].

\section{AGRADECIMIENTO}

Los autores desean expresar su reconocimiento al Fondo Nacional de Desarrollo Científico y Tecnológico, FONDECYT, por los fondos otorgados a través del proyecto N. ${ }^{2} 516 / 88$, al Programa de Dedicación Exclusiva de la Universidad de Chile, año 1988 y al Profesor Eugenio Retamal, Director del IDIEM, por su entusiasta apoyo al desarrollo de la Ciencia de Materiales.
Probabilistic Strength of Materials and Fracture Statistics, which can be established throungh Weibull's function, is being investigated at present [59].

At last there is a series of 3 works of significance for materials testing, such as quality control, random boundary conditions, and fatigue. The first work is purporting to establish regions of acceptance and rejection when testing brittle materials; for this purpose the work defines the limits between which Weibull's parameters must vary, and the number of test samples that must be used to achieve statistical validity [60]. The second work is theoretically and experimentally studying, under Professor Urrutia's direction, the influence of the boundary conditions of some test on fracture stresses, inasmuch as such conditions imply a certain randomness that must be considered in addition to material randomness [62]. The third work is investigating, also under Professor Urrutia's supervision, mechanical-fatigue process induced in compound materials, specially in the compacted composite made of copper fibre and cement; this last work is using as theoretical framework the general solution proposed for fatigue problem in the ambit of Probabilistic Strength of Materials [63].

\section{ACKNOWLEDGEMENTS}

The authors wish to thank the Fondo Nacional de Desarrollo Científico y Tecnológico (FONDECYT) fot the funds granted throungh Project $N .^{9} 516 / 88$, the Exclusive Dedication Program (1988) of the University of Chile, Professor Eugenio Retamal, Director of the IDIEM Institute, for his enthusiastic support concerning Materials Science development, and Raymond Toledo for his assistance in the redaction.

\section{REFERENCIAS}

\section{Trabajos publicados}

[1] KITTL, P.: "Transformation of a Flexural Stress Weibull's Diagram into a Tractional One". Res Mech., 1 (1980): 161-165.

[2] KITTL, P.: "Sobre la Teoría Estadística de la Fractura de Cuerpos Frágiles. I. Deducción de: la: Fórmula: de Weibull". Ceram. Vidr., 19 (1980) 407-409.

[3] KITTL, P. and CAMILO, G. M.: "Local Probability of Failure in Statistical Theory of Brittle Fracture". Res Mech. Lett., (1981) 115-118. 
[4] KITTL, P. and GÜNTHER, O.: "Volume Size and Fracture Statistics of Compacted Cement Paste". Res Mech. Lett., 1 (1981) 145-148.

[5] KITTL, P. and GALLEGUILLOS, E.: "Statistical Analysis of Decohesion in a Cu Wire/Cement Interface". Res Mech. Lett., 1 (1981) 445-449.

[6] KITTL, P.: "Isofract Three-Points Beam in the Weibull's Statistical Theory of Failure". Latin Am. J. Metall. Mater., 1 (1981) 82-83.

[7] KITTL, P. and GÜNTHER, O.: "Comments on "On Estimating the Weibull Modulus for a Brittle Material"". J. Mater. Sci., 17 (1982) 922-923.

[8] KITTL, P.: "Fracture Statistics of Surface Brittle Materials Under Flexure". J. Mater. Sci. Lett., 1 (1982) $413-415$.

[9] KITTL, P., CASTRO, J.H.C., KNAPP, W. J. and CAMILO, G. M.: "The $\chi^{2}$ Proof for Weibull's Distribution and the Anisotropy of an Electrical Porcelain". Latin Am. J. Metall. Mater., 2 (1982) 76-77.

[10] KITTL, P. and CAMILO, G. M.: "Local and Cumulative Probability of Failure in an Anisotropic Porcelain". Res Mech., 6 (1983) 127-130.

[11] KITTL, P.: "Sobre la Teoría Estadística de la Fractura de Cuerpos Frágiles. II. El Método de las Ecuaciones Integrales". Ceram. Vidr., 21 (1981) 235-237.

[12] KITTL, P. and ALDUNATE, R.: "Compression Fracture Statistics of Compacted Cement Cylinders". J. Mater. Sci., 18 (1983) $2.947-2.950$.

[13] KITTL, P.: "Volume, Surface and Interface Fracture Statistics of Brittle Materials under Flexure". Res Mech., 9 (1983) $73-86$.

[14] KITTL, P. and DIAZ, G.: "Integral Equations in Fracture Statistics of Round Beams of Brittle Materials". J. Mater. Sci. Lett., 3 (1984) 229-231.

[15] KITTL, P.: "Analysis of the Weibull Distribution Function". J. Appl. Mech., 51 (1984) 221-222.

[16] KITTL, P., BAEZA, J. and CRISOSTOMO, J.: "Fracture Statistics of a Brittle Welding". Res Mech., 12 (1984) 275-282.

[17] KITTL, P., LEON, M. and CAMILO, G. M.: "Fracture Statistics of Glass Cylinders Broken by Compression" In: Advances in Fracture Research. Eds. S.R. Valluri, D.M.R. Taplin, P. Rama Rao, J.F. Knott and R. Dubey, Pergamon Press Vol. 4, 1984, pp. 2.743-2.750.

[18] LEON, M. and KITTL, P.: "On the Dispersion of the Parameters in the Weibull Fracture Statistics". Latin Am. J. Metall. Mater., 4 (1984) 103-111.

[19] KITTL, P.: "Comments on "Relation Between Defect Position in the Bending Test and the Strength Variance". J. Mater. Sci. Lett., 4 (1985) 597-599.

[20] KITTL, P. and DIAZ, G.: "Fracture Statistics of Pull-Out of a Brittle Composite and a Short-Fibre Composite". Res Mech., 13 (1985) 43-54.

[21] KITTL, P., GALLEGUILlOS, E. and DIAZ, G.: "Properties of Compacted Copper Fibre Reinforced Cement Composite". Int. J. Cem. Compos. Lightw. Concr., 7 (1985) 193-197.

[22] LEON, M. and KITTL, P.: "On the Estimation of Weibull's Parameters in Brittle Materials". J. Mater. Sci., 20 (1985) 3.778-3.782.

[23] KITTL, P., DIAZ, G., MARIANO, W. and CASTRAL, J.: "Porosimetry and Fracture of a Hardened Cement-Paste". Latin Am. J. Metall. Mater., 5 (1985) 23-27.

[24] KITTL, P.: "On the Foundations of Fracture Statistics". Latin Am. J. Metall. Mater., 5 (1985) 85-88.

[25] DIAZ, G., KITTL, P. and KRIMAN, M.: "Statistical Mechanics of Yield Point and Fracture in Soft and Hard Welding". Reliab. Engng., 13 (1985) 239-255.

[26] KITTL, P., and DIAZ, G.: "On the Integral Equations of Weibull's Fracture Statistics". Res Mech., 18 (1986) 207-225.

[27] DIAZ, G., KITTL, P. and GALLEGUILLOS, E.: "Statistical Mechanics of Fracture and Fatigue of Compacted Copper Fibre Cement Composites". Int. J. Cem. Compos. Lightw. Concr., 8 (1986) 101-107.

[28] KITTL, P., DIAZ, G. and LEON, M.: "Trabajos Teóricos y Experimentales sobre Mecánica Estadística de Fractura, realizados en el IDIEM". Materiales de Construcción, N. ${ }^{2} 203$ (1986) 3-19.

[29] KITTL, P., CROQUEVIELLE, E., LEON, M. and DIAZ, G.: "Uncertainty of Weibull Diagram: Traction and Flexure of Terra-Cotta Beams". Cerâmica, 32 (1986) 255-258.

[30] KITTL, P. and LEON, M.: "On Fracture Statistics of Almost-Brittle Bodies". Cerâmica, 33 (1987) 55-62.

[31] KITTL, P. and DIAZ, G.: "Fracture Statistics and Low Thermal-Shock Fatigue of Asbestos-Cement Composite". Cem. Concr. Res., 17 (1987) 31-36. 
[32] DIAZ, G. and KITTL, P.: "Fracture Statistics of the Flamant and Boussinesq Problems". J. Mater. Sci. Lett., 6 (1987) $925-928$.

[33] KITTL, P., DIAZ, G., PERRET, R. and ALVAREZ, N.: "Research Work on Copper-Fibre Cement Composite carried out at the IDIEM". In: Copper 87, Physical Metalurgy of Copper, eds.: A. Varschavsky and P. Kittl. 1 (1987) pp. 279-290.

[34] KITTL, P. and DIAZ, G.: "Earthquake Risk and Fracture Statistics". Phys. Earth Planet. Inter., 49 (1987) $222-224$.

[35] KITTL, P. and DIAZ, G.: "Weibull's Fracture Statistics, or Probabilistic Strength of Materials: State of the Art. Res Mech., 24 (1988) 99-207.

[36] KITTL, P., PERRET, R., ALVAREZ, N. and DIAZ, G.: "On Durability and Mechanical Properties Improvement of a Compacted Copper-Fibre Cement Composite Subjected to General Corrosion". Cem. Concr. Res., 18 (1988) 539-544.

[37] DIAZ, G. and MORALES, M.: "Fracture Statistics of Torsion in Glass Cylinders". J. Mater. Sci., 23 (1988) 2.444-2.448.

[38] KITTL, P. and DIAZ, G.: Comment on "Debonding and Pull-Out Processes in Fibrous Composites". J. Mater. Sci. Lett., 7 (1988) 1.018-1019.

[39] DIAZ, G.: Comment on "Carbon Fibre-Thermoplastic Matrix Adhesion". J. Mater. Sci. Lett., 7 (1988) 1.042.

[40] DIAZ, G. and KITTL, P.: "On the Seewald-Karman Correction in Fracture Statistics of a Rectangular Beam". Res Mech., 24 (1988) 209-218.

[41] DIAZ, G.: "Fracture Statistics of Torsion and Dispersion Relations in Round Bars". Latin Am. J. Metall. Mater., (1988).

[42] KITTL, P. and DIAZ, G.: "On the Seewald-Karman Correstion in Fracture Statistics of Round Brittle Beams under Flexure". Engng. Fract. Mech. 32 (1989) 259-264.

[43] DIAZ, G.: Comment on "Effect of Surface Condition on the Flexural Strength of Sintered Silicon Nitride". J. Mater. Sci. Lett., 8 (1989) 619.

[44] KITTL, P. and DIAZ, G.: "Probabilistic Strength of Materials and Structural Engineering". Reliab. Engng. Syst. Saf., 25 (1989) 157-173.

\section{Trabajos en publlcación}

[45] KITTL, P., MORALES, M. and DIAZ, G.: "Probabilistic Strength of Lamellar Grey Cast Iron in Shear". J. Mater. Sci. Lett.

[46] DIAZ, G. and KITTL, P.: "Oobtention of the Specific-Risk-of-Torsional Fracture Function of a Prismatic Bar Having a Regular Polygon Cross-Section". Res Mech.

[47] LEON, M., KITTL, P., CROQUEVIELLE, E. and DIAZ, G.: "Evaluation of Weibull's Function Using Legendre's Orthogonal Polynomials". J. Mater. Sci. Lett.

[48] KITTL, P. and DIAZ, G.: "Determination of the Specific-Risk-of-Fracture Function of a Square Prismatic Bar Subjected to Torsion". Rev. Mat. Apl.

[49] KITTL, P. and DIAZ, G.: "Some Engineering Applications of the Probabilistic Strength of Materials". Appl. Mech. Reviews.

[50] KITTL, P., DIAZ, G., ALVAREZ, N. and ALDUNATE, R.: "Comparative Testing of Small Sample of Compacted Neat-Cement Paste and of Compacted Copper.Fibre Cement Composite". Engng. Fract. Mech.

[51] KITTL, P. and DIAZ, G.: "Size Effect on Fracture Strength in the Probabilistic Strength of Materials". Reliab. Engng. Sys. Saf.

[52] KITTL, P., DIAZ, G. and MARTINEZ, V.: "Probabilistic Strength of an Elliptical Bar Subjected to Torsion". Res Mech.

\section{Trabajos en elaboración}

[53] KITTL, P. and DIAZ, G.: "On Five Deductions of Weibull's Distribution Function in the Probabilistic Strenth of Materials.

[54] KITTL, P., LEON, M., DIAZ, G. and LILLO, A.: "Probabilistic Strength in Compression of Sound Dry Granite".

[55] Fracture Statistics of the Brazilian Test.

[56] Strength Reliability of Round Beams Subjected to Flexure: A Graphicall Determination of Weibull's Parameters.

[57] Obtention of the Specfic-Risk-of-Torsional Fracture Function of a Prismatic Bar Having a Rectangular Cross-Section. 
[58] Solución de la Ecuación Integral de la Resistencia Probabilistica de Materiales en Términos de un Operador Diferencial Finito.

[59] Relación entre la Probabilidad de Fractura y la Mecánica de Fractura.

[60] Control de Calidad y Resistencia Probabilística de Materiales.

[61] Autofunciones de la Ecuación Integral de la Resistencia Probabilística de Materiales de la Flexión.

[62] Condiciones de Contorno Aleatorias.

[63] Fatiga Probabilistica de Materiales Compuestos.

[64] Pandeo de Columnas de Diferentes Secciones.

[65] Tracción y Flexión de Granito.

[66] Adherencia Granito-Cemento.

[67] Ecuación Integral de la Probabilidad Local de Fractura.

[68] Torsión de Barras Prismáticas de Variadas Secciones.

[69] Recipientes Esféricos y Cilíndricos Sometidos a Presión.

[70] Campos Triaxiles.

[71] Compatibilización de la Función Riesgo Especifico de Fractura con Diferentes Ensayos.

[72] Modificación de la Función de Weibull con un Espectro Continuo del Parámetro Módulo de Weibull.

[73] Distribución de Grietas Resolviendo Ecuación Integral a partir de Datos Experimentales. Factor de Tenacidad Crítica.

[74] Promedios de las Tensiones.

[75] Ensayo de Carga Excéntrica. Tracción y Compresión.

\section{útima monografía del ICCET/CSIC (n.* 401)}

\section{DIRECTRICES DE LA UEATC PARA LA APRECIACIÓN TÉCNICA DE LOS SISTEMAS AISLANTES, SOPORTES DE IMPERMEABILIZACIONN DE CUBIERTAS PLANAS E INCLINADAS}

Traducción y adaptación: JOSE LUIS ESTEBAN SAIZ Dr. Ing. Industrial

Madrid, junio de 1990

La Unión Europea para la concesión del Documento de Idoneidad Técnica en la Construcción (UEAtc) ha elaborado estas Directrices de sistemas aislantes para soportes de impermeabilización de cubiertas planas e inclinadas las cuales han sido desarrolladas teniendo en cuenta exigencias de calidad que abarcan los aspectos de seguridad, durabilidad y puesta en obra, caracterizándose por los ensayos específicos y sistemas de control tanto internos como externos.

La Directriz está dividida en seis capítulos. En el primero se analiza la clasificación de la cubierta bajo diversos aspectos, unos de tipo constructivo y otros de los materiales que intervinieron.

En el segundo capítulo, se estudian los distintos agentes que intervienen, tanto bajo el punto de vista de la seguridad como de la durabilidad, los cuales son analizados en forma de ensayos en los capítulos tercero y cuarto.

También se dictan normas generales del tratamiento de los paneles bajo los aspectos de almacenamiento, acondicionamiento, etc...

En el capítulo quinto se estudian individualmente los materiales aislantes más comunmente utilizados como soportes de impermeabilización bajo el punto de vista de constancia de calidad.

Finalmente en los anexos se indican aclaraciones sobre el texto anterior, y terminología que se utiliza en el conjunto de la Directriz.

Precios: España, 1.900 ptas.; extranjero, \$27.00. 